\title{
ANALISIS KONDISI GEOLOGIS DAN GEOMORFOLOGIS WILAYAH SEKITAR ESCARPMENT BATURAGUNG UNTUK PENGEMBANGAN EKOWISATA
}

\author{
Oleh: \\ Muhsinatun Siasah Masruri \\ Jurusan Pendidikan Geografi FIS UNY \\ muhsinatun.siasah@uny.ac.id
}

\begin{abstract}
Abstrak
Penelitian ini bertujuan: (1) Mengidentifikasi kondisi geologis dan geomorfologis beberapa obyek alam yang menarik minat wisata, (2) Menganalisis potensi obyek tersebut untuk dikembangkan sebagai tujuan wisata. Untuk mencapai tujuan tersebut digunakan metode deskriptif-eksploratif. Populasi dalam penelitian ini adalah seluruh wilayah di sekitar Escarpment Baturagung dengan pengambilan sampel secara purposive pada beberapa obyek yang memiliki keunikan geologis dan geomorfologis serta menarik minat wisata. Data dikumpulkan dengan observasi, dokumentasi, dan studi pustaka. Analisis data menggunakan analisis deskriptif dan analisis SWOT. Hasil penelitian (1) kawasan Escarpment Baturagung berdasarkan karakteristik geologisnya dapat dikelompokkan ke dalam empat zona yaitu Parangtritis, Imogiri, Piyungan, dan Prambanan. Zona Parangtritis memiliki kondisi yang sangat kompleks dan telah banyak dikembangkan sebagai tujuan wisata. Zona Imogiri didominasi oleh hasil aktivitas vulkanik purba. Zona Piyungan sangat identik dengan kenampakan struktural. Zona Prambanan tersusun oleh berbagai jenis batuan. (2) tema pengembangan aspek scientific dalam wisata adalah: Zona Parangtritis adalah Ekowisata Geologis-Geomorfologis Kepesisiran, Zona Imogiri adalah Ekowisata Agro, Zona Piyungan adalah Ekowisata Minat Khusus, dan Zona Prambanan adalah ekowisata geologi sejarah.
\end{abstract}

Kata kunci: Escarpment Baturagung, Ekowisata

\begin{abstract}
This research aims at: (1) identifying geological and geomorphological condition of some natural objects that attract the tourists interests, (2) analyzing the potential of the objects to be developed as a tourist destination. To meet the objectives, a descriptiveexplorative research method is employed. The population includes all areas around the escarpment of baturagung. The samples were taken using a purposive sampling technique. Data were collected using an observation, documentation, and literature study. Data analysis utilizes a descriptive and SWOT analysis. The results are: (1) The escarpment of Baturagung area based on its geological characteristics can be grouped into four zones namely Parangtritis, Imogiri, Piyungan, and Prambanan. Parangtritis Zone is very complex and has been developed as a tourist destination. Imogiri Zone is dominated by the results of the ancient volcanic activity. Piyungan zone is very identical with structural appearance. Prambanan Zone is composed of various types of rocks. (2) The themes for scientific development aspects regarding the tourism are: Parangtritis Zone is Ecotourism of Coastal Geological-Geomorphological, Imogiri Zone is Agro- Ecotourism, Piyungan Zone is Special Interest of Ecotourism, and Prambanan Zone is historical-geological ecotourism.
\end{abstract}

Keywords: Escarpment of Baturagung, Ecotourism 


\section{PENDAHULUAN}

Daerah Istimewa Yogyakarta merupakan salah satu daerah tujuan wisata yang banyak dikunjungi di Indonesia. Keunikan bentangalam dan budaya mulai dari wilayah pegunungan sampai dengan pesisir menjadi faktor yang menyebabkan daerah ini banyak menjadi pilihan untuk berwisata. Pesatnya peningkatan angka kunjungan wisatawan ke Yogyakarta mendorong perkembangan obyek wisata baru. Perkembangan ini selain memberikan keuntungan secara ekonomi akan tentunya semakin bermakna apabila didukung dengan pelestarian lingkungan dan peningkatan pengetahuan masyarakat mengenai obyek alam yang dikunjungi. Dalam era modern yang ditandai dengan keterbukaan terhadap akses informasi, kegiatan pariwisata yang berbasis menikmati keindahan alam dapat didukung dengan penyampaian informasi yang ilmiah mengenai suatu obyek sehingga memiliki nilai edukatif yang bermanfaat dalam meningkatkan pengetahuan masyarakat.

Perkembangan wisata saat ini tidak hanya terbatas pada penambahan destinasi baru saja namun juga dalam konsep berwisatanya. Ekowisata merupakan salah satu bentuk wisata yang mulai banyak berkembang dan diminati. Ekowisata sebagai kegiatan pariwisata di alam bebas menjadi daya tarik bagi wisatawan. Dengan konsep ini wisatawan tidak hanya sekedar menikmati obyek wisata tetapi sekaligus juga dapat belajar mengenai lingkungan baru baik alami maupun budaya lokal yang berbeda dengan wisata lainnya.

Baiquni (2001) menjelaskan bahwa ekowisata memiliki ciri kegiatan yang berbasis keinginan untuk tahu (scientific), mengerti dan menikmati keindahan (aestetic), serta menghayati nilai dan makna (philosophical). Dengan konsep ini peminat ekowisata memiliki ciri yang berbeda dengan wisatawan pada umumnya. Dalam ekowisata, wisatawan biasanya tidak hanya peduli dengan lingkungan tetapi juga memiliki perhatian dan penghargaan pada budaya setempat. Salah satu nilai keunggulan ekowisata adalah penerapan aspek scientific yang memberikan nilai edukasi kepada wisatawan. Dengan demikian wisatawan tidak hanya diajak untuk menikmati keindahan alam tetapi juga mendapatkan informasi bernilai ilmiah mengenai obyek tersebut.

Destinasi wisata yang mendukung berkembangnya wisata bernilai edukasi seperti ekowisata umumnya memiliki keunikan alam dan keunikan budaya. Keunikan alam terbentuk oleh proses alam berupa proses geologi dan geomorfologi yang juga mempengaruhi pola kehidupan masyarakat setempat sehingga terbentuk budaya yang khas. Di wilayah sekitar escarpment baturagung terdapat beberapa obyek yang cukup banyak menarik minat masyarakat. Obyek tersebut memiliki keunikan dari segi geologi dan geomorfologi antara lain Lava Bantal Berbah Sleman, Endapan Vulkanik Purba Candi Ijo Sleman, dan Gunungapi Purba Nglanggeran Gunungkidul. Ketiga obyek tersebut termasuk dari sembilan geoheritage yang ditetapkan oleh pemerintah provinsi DIY. Penetapan geoheritage merupakan upaya untuk pelestarian situs geologi dan mengurangi dampak negatif dari perkembangan wisata (portal.jogjaprov.go.id, 2014). Hal ini sekaligus juga menunjukkan nilai ilmiah dari obyek tersebut yang perlu disampaikan kepada masyarakat.

Dengan adanya perkembangan konsep wisata dalam bentuk ekowisata, serta era keterbukaan informasi yang memungkinkan untuk memadukan unsur edukasi dalam 
wisata, maka perlu adanya identifikasi mengenai nilai ilmiah dari berbagai obyek alam yang sedang banyak diminati oleh masyarakat. Berbagai obyek yang terdapat di sekitar escarpment baturagung memiliki keunikan dari segi geologi dan geomorfologi sehingga perlu dilakukan pengkajian sebagai salah satu sumber informasi apabila akan dikembangkan sebagai obyek wisata.

\section{METODE}

Penelitian ini merupakan penelitian deskriptif yang bertujuan untuk menjelaskan gejala-gejala yang dijumpai secara terperinci. Pendekatan yang digunakan dalam penelitian ini adalah pendekatan geografi yaitu pendekatan keruangan. Tema pendekatan keruangan yang digunakan adalah tema analisis pola keruangan, analisis struktur keruangan, dan analisis sistem keruangan. Populasi dalam penelitian ini adalah seluruh wilayah di sekitar Escarpment Baturagung yang membentang mulai dari Kepesisiran Parangtritis hingga Kawasan Prambanan. Pengambilan sampel dengan purposive sampling pada beberapa obyek yang memiliki keunikan geologis dan geomorfologis serta menarik minat wisata. Data dikumpulkan melalui observasi, dokumentasi, dan studi pustaka. Analisis yang digunakan adalah analisis deskriptif dengan penekanan pada kondisi geomorfologis dan geologis. Analisis deskriptif didukung dengan analisis SWOT yaitu untuk memberikan gambaran apabila obyek yang dikaji akan digunakan sebagai destinasi ekowisata.

\section{HASIL DAN PEMBAHASAN}

\section{Daerah Penelitian}

Penelitian ini dilakukan di sekitar Escarpement Pegunungan Baturagung di wilayah Provinsi DIY. Batas daerah penelitian ditentukan mulai dari puncak Pegunungan Baturagung hingga lembah Sungai Opak yang secara geologis berkaitan dengan Escarpment Baturagung. Secara astronomis daerah penelitian antara 421302 hingga 449758 MT serta 9112615 hingga 9141503 MU pada koordinat UTM zona 49S (Gambar 1).

Berdasarkan pembagian sistem geomorfologi Pulau Jawa (Pannekoek,1949; Van Bemmelen, 1949) daerah penelitian termasuk dalam wilayah Zona Selatan Jawa Timur. Wilayah ini berupa plateau yang dikenal pula sebagai Pegunungan Selatan Jawa Timur. Terdapat beberapa unit penyusun Pegunungan Selatan Jawa Timur, Pegunungan Baturagung menempati tepi bagian paling utara yang berbatasan langsung dengan zona tengah Jawa Timur. Escarpment Baturagung merupakan batas antara Pegunungan Baturagung dengan depresi zona tengah.

\section{Gambaran Umum Kawasan Escarpment Baturagung}

Pegunungan Baturagung merupakan salah satu pegunungan yang terletak di wilayah geomorfologi zona selatan Jawa Timur. Wilayah ini membentang mulai dari perbatasan zona selatan Jawa Tengah dan Jawa Timur, dicirikan oleh pegunungan blok yang memanjang dibatasi oleh gawir sesar (escarpment). Secara geomorfologis kondisi Pegunungan Baturagung sangat kompleks baik ditinjau dari aspek genesis maupun satuan 
bentuklahannya. Hal ini tidak terlepas dari perkembangan kondisi geologis dan geomorfologis yang terjadi di Pulau Jawa sejak masa lampau.

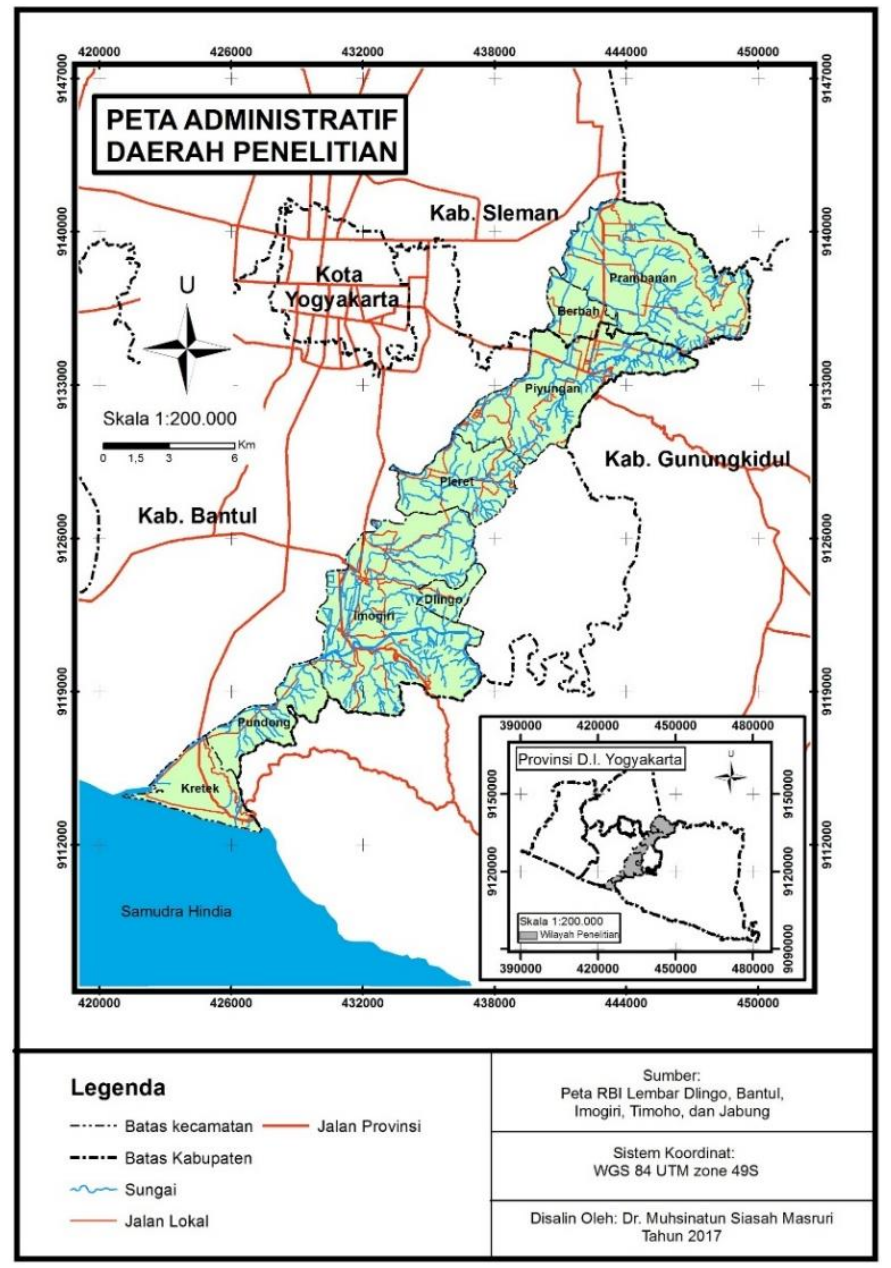

Gambar 1. Peta Daerah Penelitian

Zona selatan Jawa Timur merupakan wilayah pegunungan yang dikenal sebagai Pegunungan Selatan. Srijono dkk (2008) menjelaskan bahwa Pegunungan Selatan merupakan satuan fisiografi regional di bagian selatan Jawa yang membentang dari Teluk Ciletuh di Jawa Barat hingga Semenanjung Blambangan di ujung timur.

Pegunungan selatan tidak dijumpai di Jawa Tengah dan kedudukannya digantikan oleh dataran aluvial. Dengan demikian, zona pegunungan selatan secara umum dapat dibagi menjadi dua yaitu Pegunungan Selatan Jawa Barat dan Pegunungan Selatan Jawa Timur. Bagian barat Pegunungan Selatan Jawa Timur terbagi menjadi tiga zona yaitu bagian utara, bagian tengah, dan bagian selatan (Gambar 2). Bagian utara merupakan lajur-lajur pegunungan dengan relief yang kuat. Lajur timur dari bagian utara ini dibentuk oleh Lajur Kambengan dan Lajur Plopoh. Adapun lajur tengah dan barat dibentuk oleh Lajur Baturagung (Srijono dkk, 2008). Pannekoek (1949) menjelaskan Sepanjang tepi utara rangkaian pegunungan tersebut dibatasi oleh gawir yang curam. 


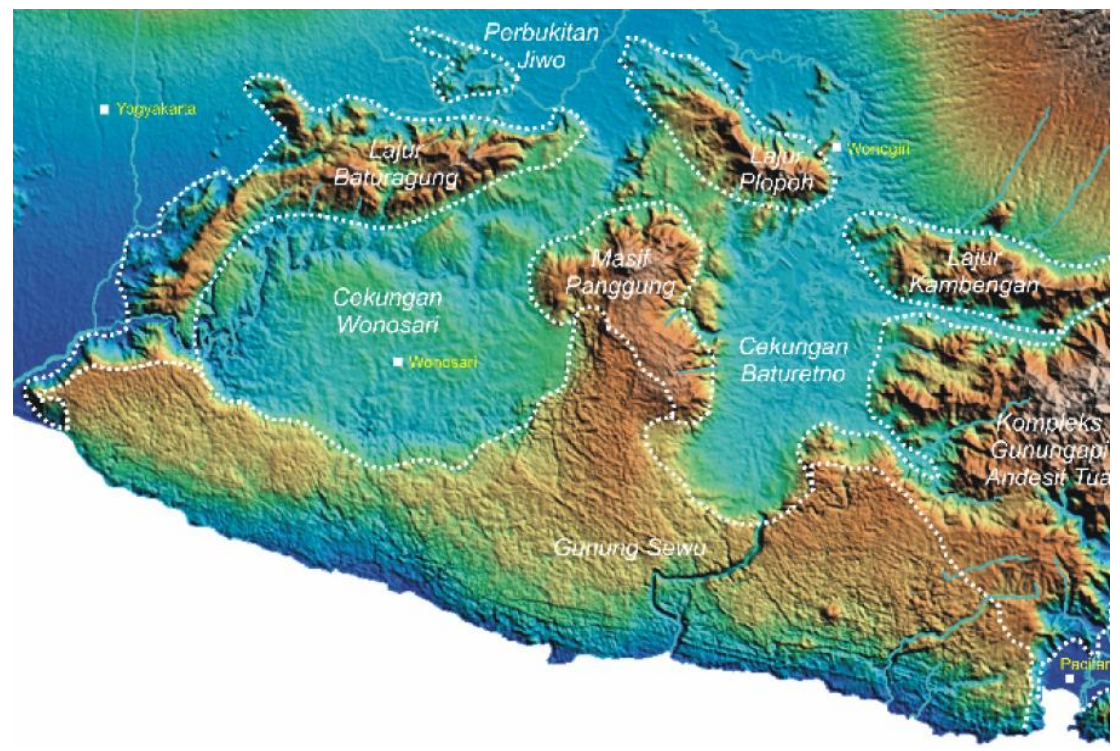

Gambar 2. Kedudukan Lajur Baturagung dalam Sistem Pegunungan Selatan Jawa Timur (Srijono dkk, 2008)

Pegunungan Selatan di wilayah Yogyakarta banyak berkaitan dengan erupsi gunungapi masa lampau. Setidaknya terdapat lima pusat erupsi purba di Pegunungan Selatan. Berdasarkan keberadaan fosil gunungapi dibedakan empat kelompok gunungapi purba yaitu: (1) Kelompok Parangtritis-Sudimoro, (2) Kelompok Baturagung-Bayat, (3) Kelompok Wonogiri-Wediombo, dan (4) Kelompok Karangtengah-Pacitan. Pada umumnya kegiatan gunung api di Pegunungan Selatan diawali oleh pembentukan lava bantal berkomposisi basal - andesit basal. Kegiatan ini berkembang ke tahap pembangunan kerucut gunung api berkomposisi lava, breksi, dan tuf berkomposisi andesit basal-andesit. Periode konstruksi tersebut diikuti fase destruksi berupa kaldera letusan yang menghasilkan breksi dan tuf pumis berkomposisi andesit silika tinggi atau dasit, bahkan riolit (Hartono dan Bronto, 2009).

Berdasarkan peta geologi Lembar Yogyakarta dan Surakarta skala 1:100.000 diketahui bahwa Pegunungan Baturagung tersusun oleh material penyusun yang sangat kompleks antara lain Formasi Kebo, Formasi Butak, Formasi Semilir, Formasi Nglanggeran, termasuk lava bantal dan batuan intrusi yang terdapat di sekitar escarpment yang membatasi pegunungan baturagung dengan zona depresi. Surono (2008) menjelaskan Formasi Kebo dan Butak tersebar di bagian lereng utara Pegunungan Baturagung yang cukup curam.

Srijono dkk (2008) menjelaskan bahwa di wilayah Pegunungan Baturagung secara geomorfologis terdapat bentuklahan vulkanik, struktural, dan fluvial. Bentuklahan vulkanik cukup dominan di Pegunungan Selatan karena aktivitas vulkanisme telah berlangsung sejak Paleogen Akhir. Bentuklahan vulkanik yang terdapat di wilayah ini berupa unit sisa vulkanik dan unit leher vulkanik. 
Bentuklahan struktural juga termasuk dalam kelompok yang mendominasi gemorfologi Pegunungan Baturagung. Srijono dkk (2008) menjelaskan bahwa bentuklahan struktural sangat dominan di wilayah ini karena pengaruh tektonik yang dominan akibat kedudukan Pegunungan Selatan yang berada di depan busur vulkanik dan senantiasa berhadapan dengan jalur penunjaman lempeng.

\section{Kondisi Geologis dan Geomorfologis Beberapa Obyek Alam di Kawasan Escarpment Baturagung yang Menarik Minat Wisata}

Untuk mempermudah dalam mengidentifikasi kondisi geologis dan geomorfologis beberapa obyek alam di Kawasan Baturagung, terlebih dahulu dibuat zonasi wilayah pembahasan dengan memperhatikan variasi kondisi fisik khususnya geologi dan geomorfologi. Pegunungan Baturagung dalam Penelitian ini dibedakan menjadi 4 zona yaitu Parangtritis, Imogiri, Piyungan, dan Prambanan (Gambar 3).

Zona Parangtritis memiliki kondisi yang sangat kompleks. Pada zona ini, Pegunungan Baturagung berbatasan langsung dengan bentuklahan karst serta marin dan eolin dalam wilayah yang tidak terlalu luas. Escarpment membatasi pegunungan dengan dataram yang perkembangan bentuklahannya dipengaruhi oleh proses eolin.

Secara geomorfologis, Escarpment Baturagung di Zona Parangtritis memiliki kedudukan yang sangat penting terhadap perkembangan bentuklahan asal poses eolin. Escarpment yang menjulang tinggi menyebabkan terbentukanya lorong angin alami, yang merupakan salah satu faktor penentu terbentuknya gumuk pasir kepesisiran di wilayah Parangkusumo. Lorong angin alami memungkinkan tiupan angin cukup kuat dengan arah konstan yang dapat membongkar endapan material sepanjang pantai.

Secara geomorfologis, selain dicirikan oleh escarpment zona ini juga dicirikan oleh bentuklahan sisa vulkanik. Unit sisa vulkanik sebagaimana dijelaskan oleh Srijono dkk (2008) berkembang di dekat Kota Kecamatan Imogiri yaitu di Gunung Sudimoro. Morfologi Gunung Sudimoro merupakan bekas erupsi dengan batuan penyusun lava dan breksi gunungapi yang saat ini telah terbiku kuat. Wilayah sisa vulkanik ini dibatasi oleh bentanglahan struktural di sekitarnya.

Zona Piyungan menempati wilayah sebelah utara Zona Imogiri. Pada zona ini selain Sesar Opak yang merupakan struktur utama dengan arah barat daya - timur laut, juga terdapat sesar dengan arah barat timur. Sesar opak dengan sesar mendatar ini termasuk dalam wilayah yang aktif secara tektonik sehingga menjadi pusat gempa termasuk yang terjadi pada 27 Mei 2006 yang diperkirakan berlokasi pada jarak $10 \mathrm{~km}$ sebelah timur Bantul (Sulaeman dkk, 2008). Zona Piyungan memiliki akses jalan raya Yogyakarta - Wonosari serta dekat dengan beberapa obyek geologi yang telah dikembangkan sebagai tujuan wisata. Dengan jarak yang relatif dekat dengan obyek lain yang telah berkembang dan keterjangkauan yang baik maka zona ini juga memiliki potensi yang cukup baik untuk dikembangkan sebagai daerah tujuan ekowisata khususnya pada aspek scientific. 


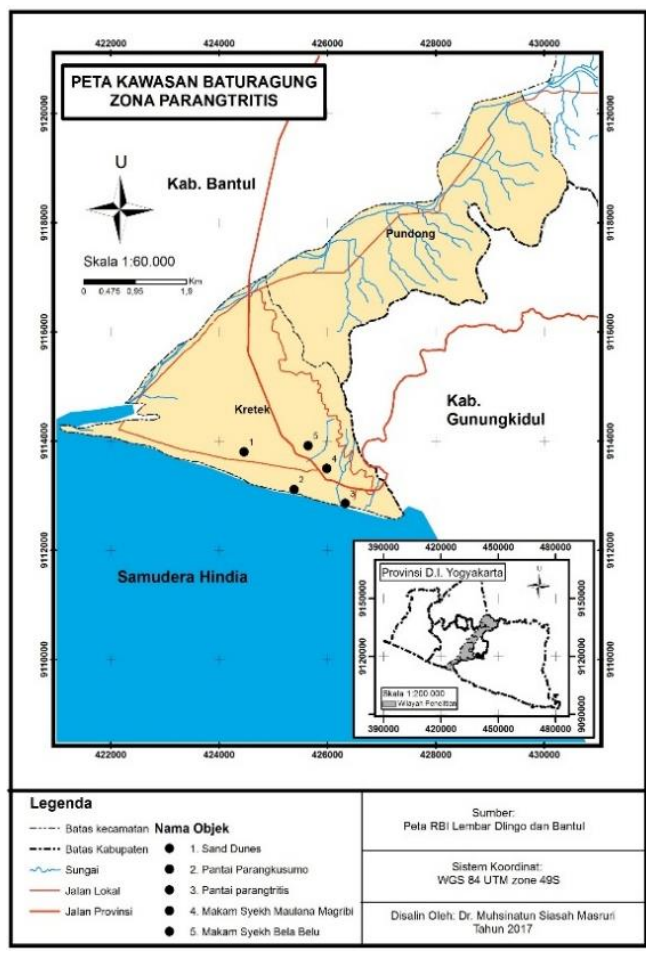

a

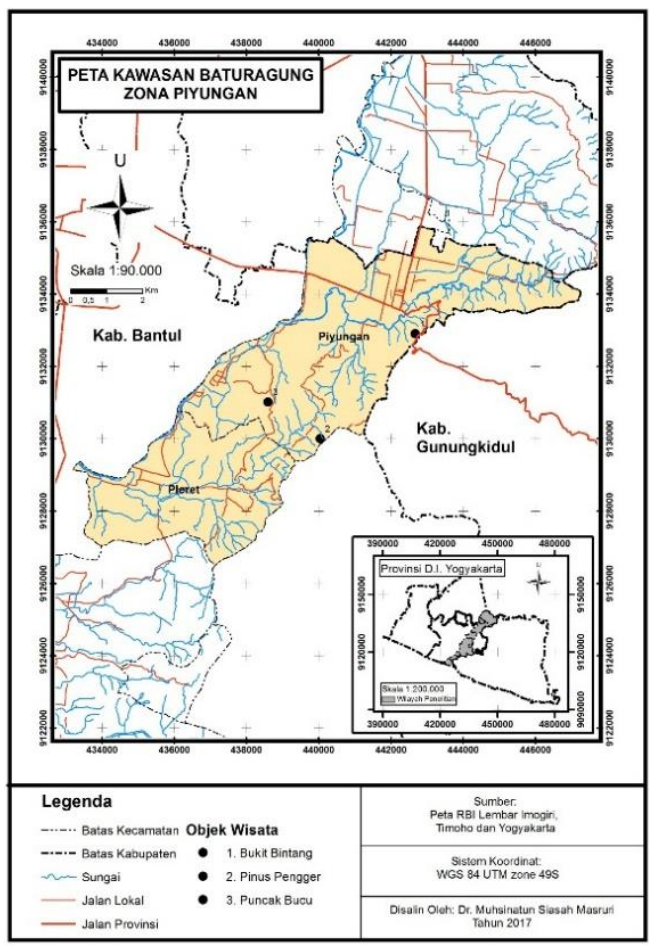

C

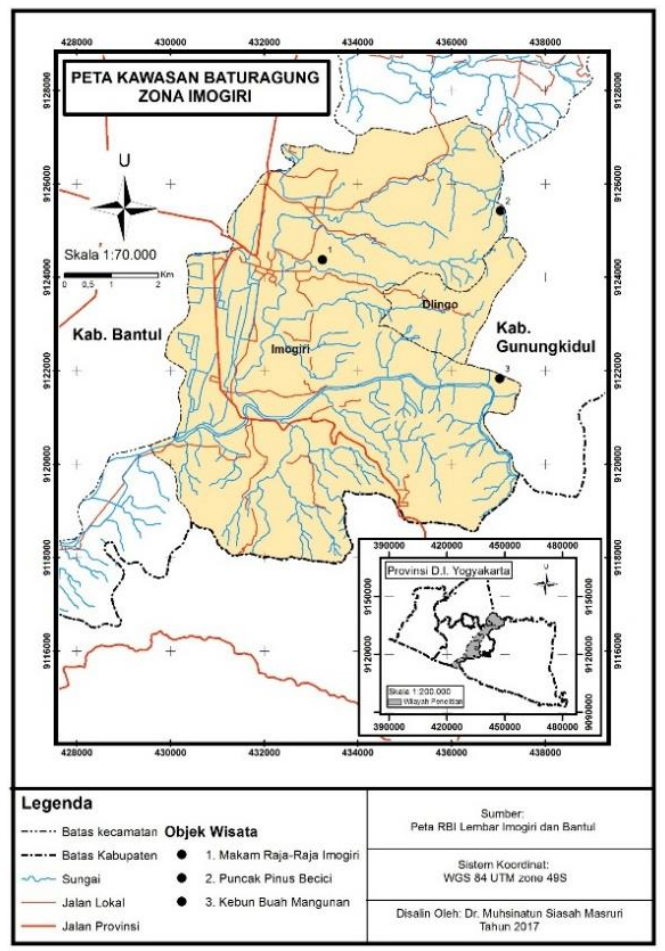

B

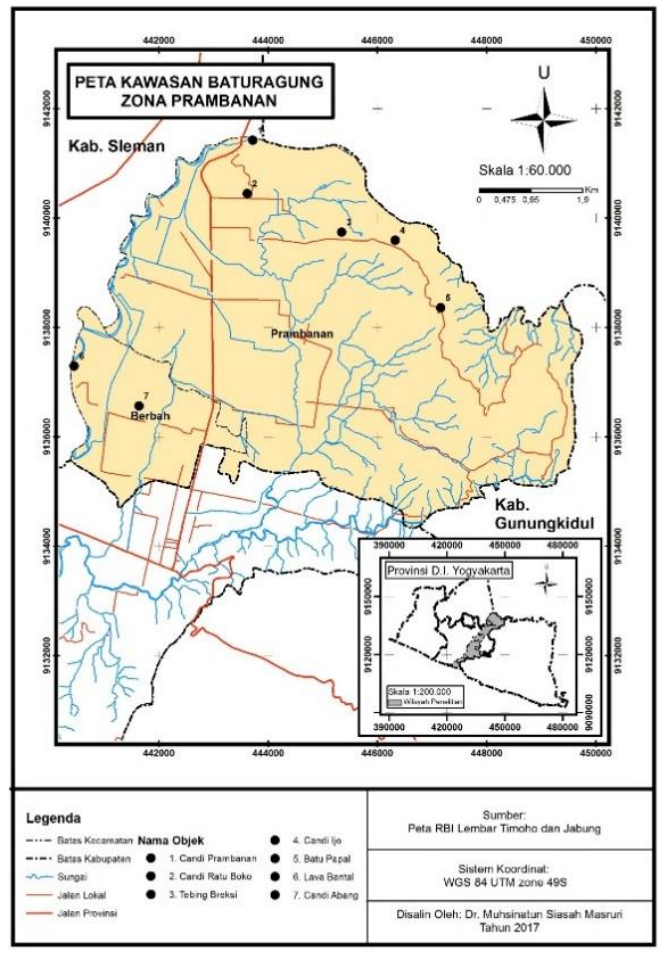

D

Gambar 3. Pembagian Zonasi Pengamatan di daerah penelitian, (a) Zona Parangtritis, (b) Zona Imogiri, (c) Zona Piyungan, (c) Zona Prambanan

Zona Prambanan menempati bagian paling utara dari daerah penelitian. Secara geologis maupun geomorfologis Zona Prambanan sangat konpleks dan beberapa obyek 
diantaranya telah berkembang dengan baik sebagai tujuan wisata. Secara geomorfologis selain Escarpment Baturagung sebagai obyek utama di wilayah ini yang mencirikan genesis struktural, pada Zona Prambanan juga terdapat beberapa bentuklahan lainnya yaitu unit leher vulkanik serta bukit terisolasi. Unit leher vulkanik terdapat di wilayah Gunungapi Purba Nglanggeran. Wilayah ini termasuk obyek geologis yang sangat terkenal di Zona Prambanan karena telah berkembang sebagai tujuan ekowisata. Leher vulkanik memiliki morfologi yang khas berupa tebing-tebing terjal yang tersusun oleh Breksi Gunungapi.

Bukit terisolasi terdapat di sebelah barat Escarpment Baturagung yang tersusun oleh batuan dari Formasi Semilir dan di sekelilingnya terdapat dataran rendah dengan material dari endapan Gunungapi Merapi muda. Jenis material penyusun bukit terisolasi yang berasal dari Formasi Semilir sama dengan yang terdapat di Pegunungan Baturagung, hal ini menandakan bukit terisolasi ini pada dasarnya merupakan bagian dari wilayah Baturagung yang mengalami penurunan akibat patahan kemudian wilayah sekitarnya terisi oleh material hasil letusan Gunungapi Merapi pada masa kuarter.

Unit geologis lain yang menarik dari Zona Prambanan adalah lava bantal di Sungai Opak yang merupakan bagian dari hasil erupsi Gunungapi Purba Watudeg. Bronto dkk (2008) menjelaskan bahwa di Kali Opak sebelah barat Dusun Watuadeg dijumpai singkapan batuan lava basal dengan panjang aliran 2 - 5 meter dan diameter 0,5 - 1 meter. Di sebelah barat Sungai Opak terdapat bukit kecil dengan tinggi sekitar 15 meter yang memiliki susunan sama dengan lava bantal sehingga diduga sebagai pusat erupsi.

\section{Potensi Obyek Alam Kawasan Baturagung untuk Dikembangkan Sebagai Tujuan Wisata}

Pada Zona Parangtritis terdapat beberapa obyek alam yang menarik minat wisata. Umumnya obyek tersebut telah dikembangkan untuk tujuan wisata baik hiburan maupun wisata spiritual. Beberapa obyek tersebut antara lain Bukit Syeh Bela Belu, Bukit Syeh Maulana Maghribi, Gumuk Pasir Parangkusumo, Pantai Parangtritis, dan Pantai Parangkusumo. Bukit Syeh Bela Belu dan Bukit Syeh Maulana Maghribi merupakan bagian langsung dari Escarpment Baturagung. Obyek ini dikelola sebagai tujuan wisata spiritual. Namun demikian obyek ini juga sangat baik apabila dikembangkan sebagai salah satu tujuan ekowisata khususnya dari aspek scientific.

Gumuk Pasir Parangkusumo merupakan obyek alam yang sangat unik. Sunarto (2014) menjelaskan di wilayah ini terdapat gumuk pasir tipe barkhan yang jarang dijumpai di daerah iklim tropis basah. Escarpment Baturagung memiliki peran dalam proses ini karena membentuk lorong angin alami sehingga menghasilkan tiupan angin yang cukup kuat. Luasan total wilayah lorong angin seluas $432,75 \mathrm{~m}^{2}$ dengan rata-rata lebar lorong angin 610,77 m dan panjang $875 \mathrm{~m}$ (Sunarto, 2014).

Pada saat ini Gumuk Pasir telah dimanfaatkan sebagai obyek wisata berupa taman gumuk pasir yang digunakan untuk spot fotografi maupun olahraga seluncur pasir (sand boarding). Pengembangan obyek wisata ini juga merupakan upaya restorasi gumuk pasir dari kerusakan. Pada saat ini di wilayah gumuk pasir masih terdapat beberapa lubang deflasi (blowout) yang menandakan bahwa terdapat proses erosi yang cukup besar oleh 
angin sehingga mengancam kelestarian gumuk pasir. Keberadaan vegetasi pada gumuk pasir sangat berpengaruh terhadap terbentuknya lubang deflasi. Pada tahun 2014 masih terdapat gumuk pasir dengan tipe lidah, memanjang, barkhan, melintang, dan nebkha (Nuraini dkk, 2016). Karakteristik geomorfologis gumuk pasir ini sangat baik apabila digunakan untuk mengembangkan ekowisata. Pada aspek scientific wisatawan dapat lebih mengenal gumuk pasir sebagai bentuklahan yang umumnya berkembang di daerah arid. Bagi guru dan siswa geografi aspek scientific dalam ekowisata di gumuk pasir dapat dimanfaatkan sebagai sumber belajar. Adapun dari aspek philosophical wisatawan dapat memahami dan menghayati berbagai proses alam yang saling berkaitan dan pentingnya menjaga kelestarian lingkungan agar gumuk pasir tidak mengalami kerusakan namun tetap lestari pada masa mendatang.

Pantai Parangtritis dan Pantai Parangkusumo juga merupakan obyek wisata yang telah sangat lama berkembang di sekitar Escarpment Baturagung Zona Parangtritis. Hasil pengamatan di lapangan menunjukkan bahwa kedua pantai ini termasuk dalam kelompok pesisir sekunder yaitu marine deposition coast. Namun demikian, walaupun sama-sama terbentuk dari proses deposisi marin, kedua pantai ini memiliki bentuk gisik yang berbeda. Pantai Parangtritis memiliki gisik yang relatif landai sedangkan Pantai Parangkusumo cederung lebih curam. Ashari dan Nuraini (2014) mengelompokkan gisik di Pantai Parangtritis ke dalam tipe gisik disipative sedangkan Pantai Parangkusumo termasuk tipe gisik intermediate.

Berdasarkan karakteristik geologis dan geomorfologis Zona Parangtritis, pengembangan ekowisata di wilayah ini direkomendasikan untuk wisata edukasi mengenai bentanglahan. Hal ini tidak terlepas dari karakteristik geomorfologis yang sangat menonjol di Zona Parangtritis, yang dicirikan oleh hubungan antar unit geomorfologi dan proses yang menghasilkan morfoaransemen. Secara lebih spesifik contoh desain pengembangan ditunjukkan oleh Tabel 1.

Zona Imogiri memiliki beberapa obyek yang telah berkembang sebagai tujuan wisata baik rekreasi maupun spiritual, antara lain Kebun Buah Mangunan, Makam Raja-Raja di Imogiri, dan Puncak Becici. Armita (2015) menjelaskan bahwa Kebun Buah Mangunan memiliki luas 23,4 hektar dengan berbagai jenis tanaman buah-buahan antara lain durian, rambutan, jeruk. Wilayah ini merupakan kawasan perbukitan dengan tanah yang kering dan tandus sehingga dipergunakan untuk pertanian lahan kering. Kebun Buah Mangunan dikembangkan dalam konsep agrowisata yang mencakup wisata pertanian dan wisata pendidikan.

Puncak Becici merupakan obyek wisata yang merupakan bagian dari Blok Mangunan. Obyek wisata ini menjadi semakin terkenal antara lain karena kunjungan dari mantan Presiden Amerika Serikat Barack Obama pada 28 Juni 2017. Puncak Becici memiliki hutan pinus seluas 4,4 hektar dengan pemandangan sunset di sore hari, serta Candi Prambanan di utara dan pantai di selatan. Sebagai bagian dari blok mangunan Puncak Becici fokus pada kegiatan alam outbond dan panorama (Yuwono, 2017). 
Tabel 1. Desain Pengembangan Ekowisata Zona Parangtritis

\begin{tabular}{|c|c|c|}
\hline No & Nama Obyek & Informasi umum \\
\hline 1 & $\begin{array}{l}\text { Gumuk Pasir } \\
\text { Parangkusumo }\end{array}$ & $\begin{array}{l}\text { - Gumuk Pasir merupakan fenomena alam yang jarang } \\
\text { dijumpai di daerah iklim tropis basah } \\
\text { - Proses pembentukan gumuk pasir sangat panjang } \\
\text { melibatkan proses vulkanik (letusan gunung merapi), } \\
\text { fluvial (aliran sungai), marin (tenaga laut), dan eolin } \\
\text { - Pesisir Parangkusumo memungkinkan terbentuknya } \\
\text { gumuk pasir karena adanya lorong angin alami yang } \\
\text { dipengaruhi tebing terjal (escarpment) } \\
\text { - Terdapat beberapa tipe gumuk antara lain barkhan, lidah, } \\
\text { parabolik, memanjang. Barkhan merupakan tipe yang } \\
\text { paling unik karena umumnya terbentuk di daerah arid } \\
\text { (gurun) }\end{array}$ \\
\hline 2 & $\begin{array}{l}\text { Pantai } \\
\text { Parangkusumo }\end{array}$ & $\begin{array}{l}\text { - Pantai ini memiliki gisik (pasir) bertipe intermediate } \\
\text { - Tipe gisik intermediate dicirikan oleh morfologi } \\
\text { berbentuk zig zag (teluk dan tanjung) } \\
\text { - Morfologi semacam ini cukup berbahaya karena } \\
\text { seringkali menjadi tempat tebentuknya arus retas (rip } \\
\text { current) yang sangat kuat }\end{array}$ \\
\hline 3 & Pantai Parangtritis & $\begin{array}{l}\text { - Pantai ini memiliki gisik (pasir) bertipe disipative } \\
\text { - Tipe gisik disipative dicirikan oleh morfologi landai } \\
\text { - Walaupun tipe gisik ini relatif aman namun wisatawan } \\
\text { disarankan untuk tetap menghindari beraktivitas di } \\
\text { daerah pecah gelombang karena gelombang samudera } \\
\text { hindia umumnya relatif besar dan membahayakan }\end{array}$ \\
\hline 4 & $\begin{array}{l}\text { Bukit Maulana } \\
\text { Maghribi dan Bela } \\
\text { Belu }\end{array}$ & $\begin{array}{l}\text { - Bukit ini merupakan bagian dari lereng terjal } \\
\text { (escarpment) pegunungan baturagung } \\
\text { - Terdapat sisa-sisa vulkanisme purba } \\
\text { - Pemandian air panas parangwedang menunjukkan gejala } \\
\text { post vulkanis } \\
\text { - Wilayah pantai dahulunya terletak pada kaki bukit-bukit } \\
\text { ini }\end{array}$ \\
\hline
\end{tabular}

Makam raja-raja mataram di Imogiri berada di wilayah Desa Girirejo dan Wukirsari. Kompleks makam di wilayah Girirejo adalah milik Keraton Surakarta sedangkan di Desa Wukirsari adalah milik Keraton Yogyakarta. Kompleks makam ini berada di perbukitan yang dikenal sebagai bukit Merak Handokopuro. Nama Imogiri diambil dari Bahasa Jawa Kuno yaitu imo berarti kabut dan giri berarti gunung (Rokhim, 2013).

Salah satu keistimewaan Zona Imogiri adalah adanya gunungapi purba yang berbentuk kerucut gunungapi komposit dan kaldera letusan. Bronto (2010) menjelaskan di daerah imogiri berdasarkan pada komposisi batuan gunungapi terdapat tiga tahapan pertumbuhan gunungapi purba yaitu pertama pembentukan gunungapi monogenesis, kedua kerucut gunungapi komposit, dan ketiga gunungapi kaldera letusan. Gunungapi monogenesis banyak dijumpai di sebelah utara Imogiri. Kerucut gunungapi komposit 
terdapat di Gunungapi Purba Sudimoro. Adapun gunungapi kaldera letusan dijumpai di Gunungapi Purba Imogiri dan Plencing-Sindet. Berdasarkan Peta Rupabumi Indonesia lembar Imogiri dan Peta Geologi Lembar Yogyakarta dapat diketahui bahwa Gunung Sudimoro memiliki ketinggian puncak 507 mdpal dengan pola aliran radial sebagaimana yang banyak dijumpai pada kerucut gunungapi.

Lebih lanjut Bronto (2010) menjelaskan, di sebelah barat Puncak Sudimoro terdapat bentangalam berupa cekungan setengah lingkaran yang membuka ke arah barat laut yang diduga sebagai bekas kawah gunungapi. Pusat gunungapi purba Imogiri diperkirakan berada di dataran dan pegunungan Imogiri yang dikelilingi oleh escarpment setengah lingkaran. Di sebelah barat laut Imogiri juga dijumpai intrusi andesit Gunung Plencing.

Dengan memperhatikan karakteristik geologis dan geomorfologis serta obyek wisata yang telah berkembang pada saat ini, desain ekowisata berbasis geologis dan geomorfologis pada Zona Imogiri direkomendasikan dalam bentuk agrowisata serta kajian gunungapi purba. Agrowisata dapat dikaitkan dengan kondisi geologis dan geomorfologis yaitu pada informasi mengenai berbagai jenis tanaman yang dapat berkembang dengan baik di wilayah tersebut yang dipengaruhi oleh kondisi lahan. Situs fosil gunungapi purba Gunung Sudimoro juga dapat dikembangkan lebih lanjut dengan memberikan informasi mengenai aktivitas vulkanik yang terjadi pada masa lampau. Contoh pengembangan aspek scientific ekowisata pada Zona Imogiri ditunjukkan oleh Tabel 2.

Tabel 2. Desain Pengembangan Ekowisata Zona Imogiri

\begin{tabular}{|c|c|c|}
\hline No & Nama Obyek & Informasi umum \\
\hline 1 & $\begin{array}{l}\text { Puncak Becici/kebun } \\
\text { buah mangunan }\end{array}$ & $\begin{array}{l}\text { - Lereng terjal di wilayah ini terbentuk dari proses } \\
\text { patahan dan disebut sebagai escarpment } \\
\text { - Ecarpment memisahkan daerah rendah dengan } \\
\text { puncak Pegunungan Baturagung dengan selisih } \\
\text { ketinggian } 400 \text { hingga } 500 \text { meter } \\
\text { - Selisih ketinggian tersebut berpengaruh terhadap } \\
\text { perbedaan fenomena cuaca khususnya suhu udara } \\
\text { - Perbedaan kondisi cuaca, batuan, dan topografi } \\
\text { berpengaruh terhadap vegetasi yang tumbuh } \\
\text { - Di wilayah ini juga terdapat beberapa gunungapi } \\
\text { purba } \\
\text { - Gunungapi purba yang dekat dengan Puncak Becici } \\
\text { dan Mangunan adalah Gunung Sudimoro }\end{array}$ \\
\hline
\end{tabular}

Pada Zona Piyungan, escarpment merupakan obyek utama yang paling menonjol selain variasi jenis batuan penyusun. Escarpment ini membatasi antara puncak Pegunungan Baturagung dan dataran rendah dengan rentang perbedaan elevasi yang cukup signifikan. Zona Piyungan memiliki lokasi yang lebih dekat dengan Kota Yogyakarta dan aksesibilitas yang baik melalui Jalan Yogyakarta - Wonosari sehingga puncak-puncak pada rangkaian Baturagung di wilayah ini banyak digunakan sebagai titik untuk menikmati keindahan panorama daerah rendah. 
Berdasarkan karakteristik geologis dan geomorfologis yang utama di Zona Piyungan, pengembangan ekowisata pada aspek geologis dan geomorfologis disarankan lebih diutamakan pada pengenalan bentanglahan struktural dengan escarpment sebagai obyek utama. Nilai-nilai edukasi yang dapat disampaikan kepada wisatawan antara lain pengertian umum mengenai escarpment, bagaimana escarpment terbentuk, apa kaitannya escarpment dengan fenomena gempa bumi, serta mengapa terdapat perbedaan ketinggian yang tegas antara puncak pegunungan dengan daerah rendah yang diamati di bawahnya. Contoh desain pengembangan ditunjukkan oleh Tabel 3.

Tabel 3. Desain Pengembangan Ekowisata Zona Piyungan

\begin{tabular}{|c|c|c|}
\hline No & Nama Obyek & Informasi umum \\
\hline 1 & Hutan Pinus Pengger & $\begin{array}{l}\text { - Titik ini merupakan salah satu puncak tertinggi di } \\
\text { Kawasan Pegunungan Baturagung } \\
\text { - Di bagian bawah terdapat hamparan dataran rendah, } \\
\text { termasuk pula Kota Yogyakarta } \\
\text { - Puncak dan dataran rendah dibatasi oleh lereng } \\
\text { curam yang banyak dikenal sebagai escarpment atau } \\
\text { gawir sesar } \\
\text { - Kondisi semacam ini menunjukkan bahwa pada masa } \\
\text { lalu pernah terjadi proses patahan yang menyebabkan } \\
\text { sebagian lahan merosot ke bawah yang disebut } \\
\text { graben seperti yang dapat kita saksikan sekarang }\end{array}$ \\
\hline 2 & Puncak Bucu & $\begin{array}{l}\text { - Salah satu puncak punggungan Baturagung } \\
\text { - Terletak tepat di atas escarpment yang berupa lereng } \\
\text { tegak } \\
\text { - Terletak pada peralihan antara wilayah batuan tuff } \\
\text { Formasi Semilir dengan breksi piroklastik Formasi } \\
\text { Nglanggran } \\
\text { - Material breksi piroklastik menunjukkan bahwa } \\
\text { wilayah ini pada masa lampau terletak dekat dengan } \\
\text { pusat erupsi vulkan }\end{array}$ \\
\hline
\end{tabular}

Zona Prambanan memiliki karakteristik yang relatif sama dengan Zona Parangtritis, yaitu terdapat banyak obyek wisata baik yang telah berkembang maupun yang baru dikembangkan. Beberapa obyek wisata yang telah lama berkembang antara lain Candi Prambanan, Candi Ratu Boko, dan Candi Ijo. Sedangkan obyek wisata yang relatif baru dikembangkan antara lain Lava Bantal Watuadeg, Tebing Breksi, dan Watu Papal.

Candi Prambanan dan Candi Ratu Boko merupakan destinasi wisata internasional. Kawasan wisata ini sudah sangat maju sehingga dapat dimanfaatkan sebagai referensi bagi pengembangan wisata di sekitarnya. Zona Prambanan memiliki keunikan dari segi geologi. Di wilayah ini terdapat dua dari sembilan warisan geologi yang ada di Provinsi DIY yaitu Lava Bantal dan Endapan Vulkanik Purba Candi Ijo. Contoh desain informasi geologis pada obyek wisata di Zona Prambanan ditunjukkan oleh Tabel 4. 
Tabel 4. Desain Pengembangan Ekowisata Zona Prambanan

\begin{tabular}{|c|c|c|}
\hline No & Nama Obyek & Informasi umum \\
\hline 1 & $\begin{array}{l}\text { Candi Ijo dan Tebing } \\
\text { Breksi }\end{array}$ & $\begin{array}{l}\text { - Di wilayah ini terdapat endapan vulkanik purba } \\
\text { - Batuan penyusun adalah tuf berukuran pasir dan } \\
\text { lempung, dan breksi pumis dasit Formasi Semilir } \\
\text { - Berdasakan karakteristik batuannya, erupsi yang } \\
\text { terjadi di masa lalu sangat eksplosif } \\
\text { - Sebelum aktivitas vulkanik semilir juga telah } \\
\text { berlangsung aktivitas vulkanik membentuk Formasi } \\
\text { Kebo Butak yang terletak di bawah batuan ini } \\
\text { - Setelah aktivitas vulkanik semilir juga berlangsung } \\
\text { aktivitas vulkanik membentuk batuan Formasi } \\
\text { Nglanggran yang terletak di atas batuan ini }\end{array}$ \\
\hline 2 & Candi Abang & $\begin{array}{l}\text { - Secara ilmiah disebut bukit terisolasi } \\
\text { - Istilah ini diberikan karena batuan penyusun bukit } \\
\text { sama dengan salah satu batuan di Pegunungan } \\
\text { Baturagung tetapi di sela antaranya terdapat } \\
\text { material berusia lebih muda yang dihasilkan dari } \\
\text { erupsi Gunung Merapi }\end{array}$ \\
\hline
\end{tabular}

\section{Strategi Pengembangan Ekowisata Berbasis Geologis dan Geomorfologis di Kawasan Baturagung}

Kawasan Baturagung secara geologis dan geomorfologis sangat unik dan bernilai tinggi. Berbagai kenampakan tersebut terbentuk dari proses panjang. Keunikan dan nilai ilmiah yang tinggi ditambah dengan keindahan panorama secara estetik perlu dinikmati dan dipahami oleh masyarakat sehingga diperlukan pengembangan ekowisata. Untuk menganalisis strategi yang dapat dilakukan dalam pengembangan ekowisata berbasis geologis dan geomorfologis digunakan analisis SWOT.

Tema pengembangan Zona Parangtritis adalah Ekowisata Geologis - Geomorfologis Kepesisiran (Tabel 5). Potensi atau kekuatan yang dimiliki zona parangtritis adalah bentanglahan yang komplek yang bersinergi sehingga membentuk beberapa kenampakan unik. Kelemahan yang dijumpai adalah penataan ruang seperti pola pemukiman pada lorong angin, keberadaan jalan penghubung yang melewati area gumuk pasir, maupun agrogenik penghutanan yang sampai saat ini belum direstorasi di area gumuk pasir aktif.

Tema pengembangan Zona Imogiri adalah Ekowisata Agro (Tabel 6). Zona Imogiri memiliki obek wisata yang beragam yang umumnya menarik wisatawan untuk datang karena keindahan panorama yang sangat baik untuk fotografi. Peluang yang ada yaitu terus berkembangnya wisata alam agro dengan kegiatan alam bebas seperti out bond dan dimugkinkan dapat berkembang lagi obyek wisata agro dengan konsep baru. Wilayah ini secara geologis juga dicirikan banyaknya gunungapi purba sehingga dapat dimanfaatkan untuk mengembangkan trail wisata edukatif berbasis geologi. Kelemahanya yaitu pengembangan ekowisata pada obyek wisata yang telah terkenal tidak dapat dilakukan dengan cepat. 
Tabel 5. Analisis SWOT Pengembangan Wisata Zona Parangtritis

\begin{tabular}{|c|c|c|}
\hline $\begin{array}{r}\text { Faktor-faktor } \\
\text { Internal }\end{array}$ & $\begin{array}{l}\begin{array}{c}\text { Strength } \\
\text { (kekuatan) }\end{array} \\
\text { (1) Potensi geologi-geomorfologi. } \\
\text { (2) Kunikan obyek geologi yang } \\
\text { beragam, tebing escarpment, lava } \\
\text { parangkusumo, gumuk pasir. (3) } \\
\text { Obyek budaya: labuhan, ritual, } \\
\text { ziarah. (4) Wisata kuliner. (5) Proses } \\
\text { deflasi yang terus berjalan tetap } \\
\text { terbentuk barkhan }\end{array}$ & $\begin{array}{l}\text { Weaknes } \\
\text { (kelemahan) }\end{array}$ \\
\hline $\begin{array}{l}\text { Oportunity } \\
\text { (peluang) } \\
\text { (1) Pesisir dengan satu-satunya } \\
\text { bentukan gumuk pasir barkhan } \\
\text { sehingga berpotensi sebagai } \\
\text { wisata internasioal berbasis ilmu } \\
\text { pengetahuan. (2) Gumuk pasir } \\
\text { sebagai salah satu warisan geologi } \\
\text { terdapat di zona ini }\end{array}$ & $\begin{array}{l}\text { SO } \\
\text { Pengembangan yang dinamis } \\
\text { saling mendukung antar peisir } \\
\text { paangtritis yang berkaitan dengan } \\
\text { pesisir parangkusumo. }\end{array}$ & $\begin{array}{c}\text { WO } \\
\text { Tata ruang yang tepat }\end{array}$ \\
\hline $\begin{array}{l}\text { Threat } \\
\text { (tantangan) } \\
\text { (1) Mempertahankan kelestarian } \\
\text { obyek geologis. (2) Meminimalkan } \\
\text { koflik pemanfaatan lahan }\end{array}$ & $\begin{array}{l}\text { ST } \\
\text { Dukungan pelestarian yang ada } \\
\text { Restorasi gumuk pasir }\end{array}$ & $\begin{array}{l}\text { WT } \\
\text { Hambatan yang ada } \\
\text { Perlu dilakukan banyak } \\
\text { pengembangan }\end{array}$ \\
\hline
\end{tabular}

Tabel 6. Analisis SWOT Pengembangan Wisata Zona Imogiri

\begin{tabular}{|c|c|c|}
\hline 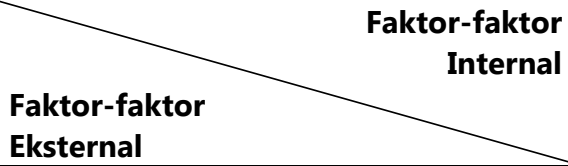 & $\begin{array}{c}\text { Strength } \\
\text { (kekuatan) }\end{array}$ & $\begin{array}{l}\quad \begin{array}{l}\text { Weaknes } \\
\text { (kelemahan) }\end{array} \\
\text { Faktor topografi yang } \\
\text { menjadi hambatan }\end{array}$ \\
\hline $\begin{array}{l}\text { Oportunity } \\
\text { (peluang) }\end{array}$ & \begin{tabular}{lrr}
\multicolumn{3}{c}{ SO } \\
Kesesuaian & lahan & untuk \\
tanaman merupakan salah satu \\
solusi pengembangan. \\
Inovasi & mengkombinasikan \\
informasi & geologi & dengan \\
agrowisata & yang & telah \\
berkembang & &
\end{tabular} & $\begin{array}{l}\text { WO } \\
\text { Ekowisata masih } \\
\text { harus di kembangkan }\end{array}$ \\
\hline $\begin{array}{l}\text { Threat } \\
\text { (tantangan) } \\
\text { Pengeloaan vegetasi dan obyek yang } \\
\text { tepat agar dapat diperoleh hasil yang } \\
\text { optimal }\end{array}$ & \begin{tabular}{lr}
\multicolumn{1}{c}{ ST } & \\
Pelestarian vegetasi, & perlu \\
memperhatikan & kondisi \\
geologi dan topografi &
\end{tabular} & $\begin{array}{l}\text { WT } \\
\text { Perawatan vegetasi } \\
\text { tertentu agar hasil } \\
\text { maksimal }\end{array}$ \\
\hline
\end{tabular}

Tema pengembangan Zona Piyungan adalah Ekowisata Minat Khusus (Tabel 7). Pengembangan wisata dapat diarahkan untuk pengenalan bentanglahan struktural dengan kombinasi wisata petualangan yang berupa outbond. Escarpment merupakan obyek utama untuk pengembangan ekowisata berbasis geologi dan geomorfologi. 
Tabel 7. Analisis SWOT Pengembangan Wisata Zona Piyungan

\begin{tabular}{|c|c|c|}
\hline $\begin{array}{l}\text { Faktor-faktor } \\
\text { Eksternal }\end{array}$ & $\begin{array}{l}\text { Strength } \\
\text { (kekuatan) } \\
\text { (1) Potensi wisata dengan } \\
\text { keindahan panorama dari atas } \\
\text { escarpment. (2) Terdapat jalur } \\
\text { utama Yogyakarta - Wonosari } \\
\text { sehingga akses relatif mudah }\end{array}$ & $\begin{array}{l}\text { Weaknes } \\
\text { (kelemahan) } \\
\text { Pengembangan } \\
\text { wisata masih } \\
\text { terbatas pada } \\
\text { penawaran dari atas } \\
\text { panorama da } \\
\text { escarpment }\end{array}$ \\
\hline 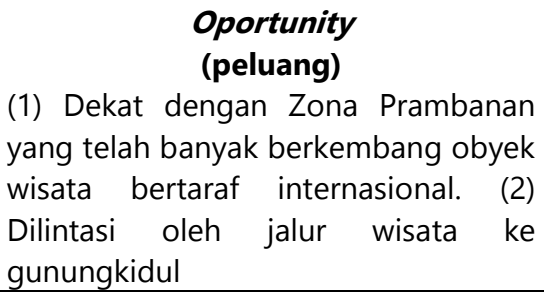 & $\begin{array}{l}\text { SO } \\
\text { Dapat berkembang menjadi obyek } \\
\text { wisata baru dengan konsep wisata } \\
\text { petualangan dan pengetahuan } \\
\text { geologis yang berfungsi sebagai } \\
\text { obyek wisata satelit Yogyakarta } \\
\text { dan Gunungkidul }\end{array}$ & $\begin{array}{l}\text { WO } \\
\text { Pengenalan konsep } \\
\text { ekowisata dan } \\
\text { penyampaian } \\
\text { informasi geologis- } \\
\text { geomorfologis }\end{array}$ \\
\hline 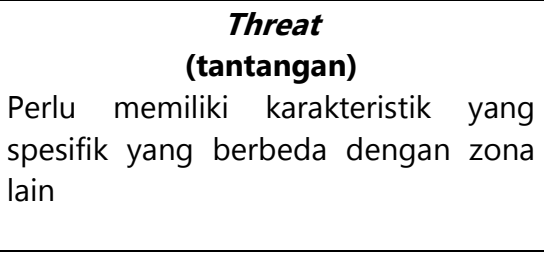 & 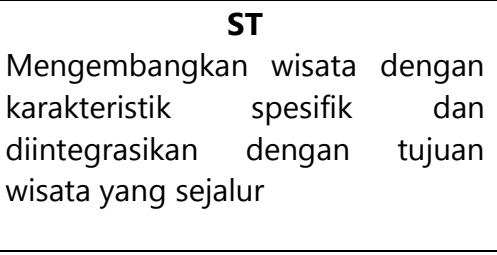 & \begin{tabular}{l}
\multicolumn{1}{c}{ WT } \\
Memperkuat \\
pemahaman \\
ekowisata, \\
mengembangkan \\
konsep yang spesifik
\end{tabular} \\
\hline
\end{tabular}

Tema pengembangan Zona Prambanan adalah ekowisata geologi sejarah (Tabel 8). Hal ini didukung oleh potensi yang ada di wilayah ini baik potensi sejarah masyarakat maupun sejarah geologi. Kekuatan Zona Prambanan untuk pengembangan ekowisata antara lain lokasi yang relatif dekat dengan Kota Yogyakarta, kedudukan diantara Kota Yogyakarta dan Surakarta, aksesibilitas yang baik, prasarana dan sarana yang telah tersedia.

Tabel 8. Analisis SWOT Pengembangan Wisata Zona Prambanan

\begin{tabular}{|c|c|c|}
\hline $\begin{array}{l}\text { Faktor-faktor } \\
\text { Eksternal }\end{array}$ & \begin{tabular}{l}
\multicolumn{1}{c}{$\begin{array}{c}\text { Strength } \\
\text { (kekuatan) }\end{array}$} \\
Terdapat obyek wisata bertaraf \\
internasional. \\
Memiliki prasarana dan sarana \\
wisata yang sangat maju. \\
Terletak dekat dengan Kota \\
Yogyakarta
\end{tabular} & \begin{tabular}{cr}
\multicolumn{2}{c}{$\begin{array}{c}\text { Weaknes } \\
\text { (kelemahan) }\end{array}$} \\
Peran pengelola & kegiatan \\
ekowisatar untuk & sosialisasi $\quad$ kepada \\
wisatawan khususnya \\
mengenai aspek scientific \\
dan philosophical \\
\end{tabular} \\
\hline $\begin{array}{l}\text { Oportunity } \\
\text { (peluang) } \\
\text { Obyek wisata bertaraf internasional } \\
\text { dapat menjadi media promosi } \\
\text { pengembangan obyek wisata lain } \\
\text { Terletak diantara dua kota besar } \\
\text { yang banyak menjadi tujuan wisata } \\
\text { budaya }\end{array}$ & $\begin{array}{l}\text { SO } \\
\text { Implementasi ekowisata aspek } \\
\text { scientific dan philosophical } \\
\text { mengenai sejarah geologi dan } \\
\text { masyarakat }\end{array}$ & $\begin{array}{l}\text { WO } \\
\text { Interkonksi antara obyek } \\
\text { wisata yang telah maju } \\
\text { dengan obyek wisata } \\
\text { yang } \\
\begin{array}{lr}\text { dikembangkan sedang } \\
\end{array}\end{array}$ \\
\hline \begin{tabular}{l}
\multicolumn{1}{c}{$\begin{array}{c}\text { Threat } \\
\text { (tantangan) }\end{array}$} \\
Pelestaraian dan mempertahankan \\
obyek warisan masa lampau dengan \\
perawatan yang benar
\end{tabular} & $\begin{array}{l}\text { Mengoptimalkan potensi yang } \\
\text { dimiliki dengan mengelola } \\
\text { obyek secara baik }\end{array}$ & $\begin{array}{l}\text { WT } \\
\text { Rekonstruksi candi dan } \\
\text { informasi sejarah geologi } \\
\text { yang memerlukan proses } \\
\text { yang detil dan data yang } \\
\text { lengkap }\end{array}$ \\
\hline
\end{tabular}


Dari segi geologi, Zona Prambanan memiliki dua dari sembilan warisan geologi yang ada di Provinsi DIY yaitu Lava Bantal dan Endapan Vulkanik Purba Candi Ijo. Kelemahan Zona Prambanan adalah sejarah geologi belum disosialisasikan secara optimal. Selain itu konsep ekowisata yang melibatkan pengunjung dalam aspek scientific dan philosophical perlu ditingkatkan melalui sosialisasi dari pengelola.

\section{SIMPULAN}

Escarpment Baturagung memiliki kondisi geologis dan geomorfologis yang sangat kompleks. Kondisi geologis dan geomorfologis ini memiliki nilai ilmiah yang sangat tinggi. Disisi lain di kawasan Escarpment Baturagung juga telah banyak berkembang obyek wisata. Berdasarkan kondisi tersebut dapat dikembangkan ekowisata dengan tiga aspek yaitu aspek scientific, aestethic, dan philosophical. Dengan demikian nilai-nilai ilmiah di kawasan Escarpment Baturagung dapat disampaikan kepada masyarakat secara terintegrasi dengan aktivitas wisata. Berdasarkan karakteristik geologis geomorfologis dan obyek wisata yang telah berkembang saat ini, Escarpment Baturagung dapat dibedakan menjadi empat zona yaitu Zona Parangtritis, Zona Imogiri, Zona Piyungan, dan Zona Prambanan. Masingmasing zona memiliki kekuatan, kelemahan, peluang, dan ancaman yang berbeda.

\section{UCAPAN TERIMA KASIH}

Penelitian ini dibiayai dengan dana DIPA Fakultas Ilmu Sosial Universitas Negeri Yogyakarta Tahun 2017 melalui Hibah Penelitian Bidang Keahlian Tahun 2017. Penulis mengucapkan terima kasih yang sebesar-besarnya kepada FIS UNY yang telah membiayai penelitian ini. Secara khusus penulis juga mengucapkan terima kasih kepada saudara Arif Ashari, M.Sc. untuk berbagai diskusi yang dilakukan dengan penulis selama kegiatan penelitian.

\section{DAFTAR PUSTAKA}

Armita, R. 2015. Potensi Agrowisata Kebun Buah Mangunan dan Upaya Pengembangannya di Desa Mangunan Kecamatan Dlingo Kabupaten Bantul. Skripsi. Fakultas Ilmu Sosial Universitas Negeri Yogyakarta.

Ashari, A dan Nuraini, F. 2014. Kajian Tipe Gisik Sebagai Arahan Pengelolaan Wilayah Kepesisiran Kabupaten Bantul. Prosiding PIT IGI XVII, Yogyakarta 2017.

Bronto, S., Mulyaningsih, S., Hartono, G., dan Astuti, B. 2008. Gunung Api Purba Watuadeg: Sumber Erupsi dan Posisi Stratigrafi. Jurnal Geologi Indonesia 3 (3): 117-128

Bronto, S. 2010. Publikasi Khusus Geologi Gunungapi Purba. Jakarta: Badan Geologis

Hartono, H.G. dan Bronto, S. 2009. Analisis Stratigrafi Awal Kegiatan Gunung Api Gajahdangak di Daerah Bulu, Sukoharjo: Implikasinya Terhadap Stratigrafi Batuan Gunung Api di Pegunungan Selatan, Jawa Tengah. Jurnal Geologi Indonesia 4 (3): 157-165

Nuraini, F., Sunarto., dan Santosa, L.W. 2016. Pengaruh Vegetasi Terhadap Dinamika Perkembangan Gumuk Pasir di Pesisir Parangkusumo. Geomedia 14 (2): 107-117 
Rokhim, M.N. 2013. Unsur Religi dalam Tradisi Nguras Enceh di Makam Raja-Raja Imogiri. Skripsi. Fakultas Bahasa dan Seni Universitas Negeri Yogyakarta.

Santosa, L.W., Sartohadi, J., dan Mutaali, L. 2004. Identifikasi Kerusakan Lahan dan Cara Pemulihan Kualitas Lingkungan Zona Utara (Baturagung) Kabupaten Gunungkidul. Laporan Penelitian. Kantor Pengendalian Dampak Lingkungan Kabupaten Gunungkidul

Srijono., Husein, S., Haryono, E., Yuwono, S.E., Samodra, H., Rachwibowo, P., dan Budiadi, E. 2008. Penerapan Pemetaan Geomorfologi Metode ITC dalam Menganalisis Geomorfologi Pegunungan Selatan Jawa Timur. Prosiding Pertemuan IImiah Tahunan IAGI ke-37

Sulaeman, C., Dewi, L.C., dan Triyoso, W. 2008. Karakterisasi Sumber Gempa Yogyakarta 2006 Berdasarkan Data GPS. Jurnal Geologi Indonesia 3 (1): 49-56

Sunarto. 2014. Geomorfologi dan Kontribusinya dalam Pelestarian Pesisir Bergumuk Pasir Aeolian dari Ancaman Bencana Agrogenik dan Urbanogenik. Pidato Pengukuhan Jabatan Guru Besar Pada Fakultas Geografi Universitas Gadjah Mada. 2 April 2014.

Surono. 2008. Litostratigrafi dan Sedimentasi Formasi Kebo dan Formasi Butak di Pegunungan Baturagung, Jawa Tengah Bagian Selatan. Jurnal Geologi Indonesia 3 (4): $183-193$

Yuwono, M. 2017. Keindahan Puncak Becici, Lokasi yang Diminati Obama. dalam http://regional.kompas.com/read/2017/06/28/15534591/keindahan.puncak.becici.l okasi.yang.diminati.obama diakses 3 September 2017. 